Arch Virol (1989) 109: 185-196

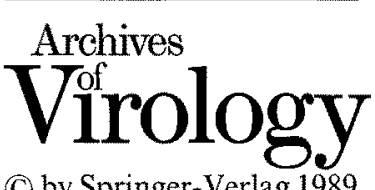

(C) by Springer-Verlag 1989

\title{
Characterization of a temperature sensitive feline infectious peritonitis coronavirus
}

\author{
K. K. Christianson, J. D. Ingersoll, R. M. Landon, N. E. Pfeiffer, and J. D. Gerber \\ Biological Research and Development, Norden Laboratories, Lincoln, Nebraska, U.S.A.
}

Accepted September 20, 1989

\begin{abstract}
Summary. The characteristics of a temperature sensitive feline infectious peritonitis virus (TS-FIPV) were examined. TS-FIPV, unlike its parent strain, DF2 wild type FIPV (WT-FIPV), propagated at $31^{\circ} \mathrm{C}$ (permissive temperature) but not at $39^{\circ} \mathrm{C}$ (nonpermissive temperature). This temperature preference of TSFIPV was also demonstrated in cats by the ability of the virus to replicate only at the lower temperature in the upper respiratory tract and not at systemic sites where higher temperatures $\left(38-39^{\circ} \mathrm{C}\right)$ prevail. Viral structural proteins and RNA were synthesized at $39^{\circ} \mathrm{C}$ but some undefined maturational defect prevented the formation of infectious TS-FIPV at its nonpermissive temperature. TSFIPV was more thermolabile than WT-FIPV which indicated alterations in the structural proteins of TS-FIPV, and a difference in the envelope protein of the two viruses was revealed by Western blot analysis. Plaque assay characterization showed that TS-FIPV produced small plaques in comparison to the large plaques of WT-FIPV. These unique characteristics possessed by TS-FIPV may account for its nonvirulent nature and ability to stimulate protective immune responses in cats.
\end{abstract}

\section{Introduction}

Feline infectious peritonitis (FIP) is a complex and fatal disease of cats caused by infection with feline infectious peritonitis virus (FIPV). Previous attempts to consistently protect cats by immunization with other antigenically related coronaviruses such as porcine transmissible gastroenteritis virus (TGEV) [26], canine coronavirus (CCV) [2], and human coronavirus [1] have been unsuccessful. Inconsistent protection was found when cats were given a sublethal dose of virulent FIPV and cats vaccinated with an avirulent FIPV were more easily infected than were nonvaccinated cats [14]. Recently, it has been demonstrated that an intranasally (IN) administered temperature sensitive FIPV (TS-FIPV) vaccine is efficacious and safe upon FIPV challenge [5]. 
The pathogenesis of FIP is complicated and not fully understood. Evidence indicates that FIP is an immune-mediated disease [10]. The virus has been shown to replicate initially in the upper respiratory tract and small intestine [20]. Macrophages, the primary FIPV target cell, may then cross the mucosal barrier and spread virus throughout the cat $[8,24,25]$. Furthermore, a correlation between FIPV virulence in vivo and ability to infect macrophages in vitro has been observed [18]. It has been suggested that a strong cell-mediated immune response to FIPV may be more important than humoral immunity in protecting cats from this disease $[15,19]$. However, the role of local immune responses in the upper respiratory tract and intestinal tract has not been carefully evaluated and may represent an important immune defense mechanism against FIP.

TS-FIPV was developed by serial passages at a reduced temperature, followed by ultraviolet irradiation. The selected virus will propagate at its permissive temperature $\left(31^{\circ} \mathrm{C}\right)$ but not at its nonpermissive temperature $\left(39^{\circ} \mathrm{C}\right)$. Temperature sensitivity was accompanied by the appearance of various characteristics that distinguish TS-FIPV from its virulent parent strain. The purpose of this report is to present these distinguishing characteristics which include plaque size, temperature stability, ability to synthesize RNA, expression of structural proteins and temperature dependent replication in vitro and in vivo.

\section{Materials and methods}

Cell culture

Norden Laboratories feline kidney (NLFK) cells were used from passage 80 to 92 . Cells were propagated in Basal Medium Eagle (BME) supplemented with 5\% fetal bovine serum (FBS) and $10 \mathrm{mM}$ Hepes buffer.

\section{Virus isolation}

The DF2 wild type FIP virus (WT-FIPV) was originally isolated from a cat liver explant. After several passages of tissue homogenates in specific pathogen free (SPF) cats, the virus was adapted to NLFK cells by cocultivation with infected primary spleen cells. The DF2 WT-FIPV strain was grown on NLFK cells at $39^{\circ} \mathrm{C}$ for passages 1 through 60 and then passed at $31^{\circ} \mathrm{C}$ up to passage 99 . The virus collected at passage 99 was ultraviolet irradiated ( $5 \mathrm{~cm}$ distance with a Westinghouse $782-30$ lamp, $118 \mathrm{~V}, 60 \mathrm{cycles}, 0.5 \mathrm{amps}$ ) for $5 \mathrm{~min}$. The virus was plaque purified and designated TS-FIPV. Passage 13 of the plaque purified TSFIPV was used in the characterization studies.

\section{Plaque assay, growth curve, and virus titration}

The plaque assay was done with confluent cell monolayers inoculated with $0.2 \mathrm{ml}$ of a tenfold virus dilution. After adsorption for $1 \mathrm{~h}$ at $31^{\circ} \mathrm{C}$ or $39^{\circ} \mathrm{C}$, the cells were overlaid with $4 \mathrm{ml}$ of $0.75 \%$ carboxymethylcellulose in 199 medium. Monolayers were fixed and stained with a solution of $10 \%$ formalin, $1 \%$ crystal violet and $20 \%$ ethanol $72 \mathrm{~h}$ postinfection.

Viral growth curves were conducted to compare the growth of TS-FIPV and WT-FIPV at both $31^{\circ} \mathrm{C}$ and $39^{\circ} \mathrm{C}$. TS-FIPV and WT-FIPV were inoculated onto confluent cell monolayers at a multiplicity of infection (m.o.i.) of approximately 0.1 . At predetermined 
times over $65 \mathrm{~h}$, viral fluids were aseptically removed, stored at $-80^{\circ} \mathrm{C}$, and titrated for infectivity at the completion of the growth curve. The TCID $_{50}$ assay for virus infectivity was done in 96-well microtiter plates by infection of 5 wells each with $100 \mu \mathrm{l}$ of a tenfold virus dilution. TS-FIPV was titered at $31^{\circ} \mathrm{C}$ and WT-FIPV was titered at $39^{\circ} \mathrm{C}$. Wells were examined for cytopathic effects (CPE) on day 5 and the method of Reed and Muench [16] was used to calculate the $\mathrm{TCID}_{50}$.

\section{Thermolability}

Thermolability studies were performed at $54^{\circ} \mathrm{C}$ with WT-FIPV and TS-FIPV. Each virus was diluted 1:5 in serum-free BME. At intervals between 5 and $75 \mathrm{~min}$, samples were removed, immediately cooled in an ice bath and titrated for residual infectivity.

\section{Viral RNA synthesis}

NLFK cells were used to determine TS-FIPV virus-specific RNA synthesis. Cell monolayers were infected at an m.o.i. of approximately 10 for $1 \mathrm{~h}$ at $31^{\circ} \mathrm{C}$. After removal of the inoculum, $2 \mathrm{ml}$ of BME containing $2 \%$ dialyzed FBS, $1 \mu \mathrm{g} / \mathrm{ml}$ actinomycin $\mathrm{D}$ and $25 \mu \mathrm{Ci}\left[5^{-}{ }^{3} \mathrm{H}\right]-$ uridine was added to duplicate cultures. Following incubation for $12 \mathrm{~h}$, the radiolabeled cellular RNA was extracted according to Miller et al. [12]. The RNA pellets were solubilized in Readi-Protein (Beckman, Fullerton, CA) and counted in a liquid scintillation counter (Model LS3801, Beckman Instruments, Fullerton, CA).

A parallel set of cultures without radiolabel was used to monitor infectivity. The unlabeled cells and medium collected at $12 \mathrm{~h}$ were titrated after one freeze-thaw cycle.

\section{Monoclonal antibodies}

Spleen cells from BALB/c mice immunized with either CCV or WT-FIPV were fused with NS 1/Ag 4 mouse plasmacytoma cells (American Type Cell Culture, Rockville, MD) using standard procedures [13]. Hybridoma culture fluids were screened for specific antibody production by ELISA and Western blot. Selected hybridomas were cloned twice by limiting dilution and ascites was produced by intraperitoneal injection of $5 \times 10^{6}$ hybridoma cells into pristane-treated $\mathrm{BALB} / \mathrm{c}$ mice.

The monoclonal antibodies chosen for use in this study were broadly cross-reactive against CCV, FIPV, and feline enteric coronavirus (FECV). Three antibodies designated Mab-P, Mab-N, and Mab-E were selected based on their specificities for the peplomer protein (Mab-P), nucleocapsid protein (Mab-N) and envelope protein (Mab-E). Mab-P and Mab-N were obtained from a fusion performed with a CCV-immunized mouse and Mab-E originated from a mouse immunized with WT-FIPV. All three antibodies were used as the primary antibody in the Western blot and indirect immunofluorescence assays (IFA) (see below).

\section{Comparison of WT-FIPV and TS-FIPV structural proteins}

The structural proteins of WT-FIPV grown at $39^{\circ} \mathrm{C}$ and TS-FIPV grown at $31^{\circ} \mathrm{C}$ were examined by SDS-PAGE and Western blot. SDS-PAGE was performed by a modified Laemmli system [9]. After electrophoresis, the proteins were blotted to Immobilon PVDF Transfer Membrane (Millipore, Bedford, MA) by the procedure of Towbin et al. [22]. Following transfer, the blot was blocked with $2 \%$ nonfat dried milk in PBS, incubated with Mab-P, Mab-N, or Mab-E and then reacted with alkaline phosphatase-conjugated goat anti-mouse IgG $(\mathrm{H}+\mathrm{L})$ (Kirkegaard and Perry, Gaithersburg, MD).

\section{TS-FIPV proteins at permissive and nonpermissive temperature}

TS-FIPV proteins in supernatants from cells infected at $31^{\circ} \mathrm{C}$ and $39^{\circ} \mathrm{C}$ were examined by Western blot. NLFK monolayers were infected at an m.o.i. of approximately 1 or 10 for 
$1 \mathrm{~h}$ at $31^{\circ} \mathrm{C}$ or $39^{\circ} \mathrm{C}$. The inocula were removed, the cultures were washed twice with BME and finally $2 \mathrm{ml}$ of BME was added. At intervals between 0 and $96 \mathrm{~h}$ post-adsorption, the culture medium was removed and centrifuged $(13,000 \times \mathrm{g})$ for $10 \mathrm{~min}$. The supernatants were frozen at $-80^{\circ} \mathrm{C}$ until Western blot analysis.

\section{Immunofluorescence microscopy}

WT-FIPV and TS-FIPV intracellular and surface antigens expressed at $31^{\circ} \mathrm{C}$ and $39^{\circ} \mathrm{C}$ were examined by an indirect IFA [7]. Cell monolayers were infected with WT-FIPV and TS-FIPV at an m.o.i. of approximately 0.1 . At the appropriate time point the cells were rinsed with PBS and then fixed in acetone for $20 \mathrm{~min}$ at $-20^{\circ} \mathrm{C}$. The slides were then exposed to Mab-P, Mab-N, or Mab-E for 30 min at $37^{\circ} \mathrm{C}$. Following incubation, the slides were rinsed in PBS and then exposed to fluorescein-conjugated goat anti-mouse $\operatorname{IgG}(\mathrm{H}+\mathrm{L})$ (Kirkegaard and Perry, Gaithersburg, MD) for $30 \mathrm{~min}$ at $37^{\circ} \mathrm{C}$. Detection of viral surface antigens by indirect IFA was done as described for detection of intracellular antigens except the monolayers were not fixed. The cells were observed and photographed with a Zeiss Axioskop photomicroscope equipped with a Zeiss $\times 40$ objective.

\section{In vivo fate of the virus}

SPF cats (Liberty Labs, Liberty Corner, NJ), 10 to 20 months old, were used in this study. Three cats were vaccinated IN with $1 \mathrm{ml}$ of TS-FIPV $\left(10^{6.75} \mathrm{TCID}_{50} / \mathrm{ml}\right)$. At 1,2 , and 4 days after inoculation one TS-FIPV vaccinated cat was sacrificed. One cat was infected orally with WT-FIPV $\left(10^{6.23} \mathrm{TCID}_{50} / \mathrm{ml}\right)$ and sacrificed on day 4 .

After sacrifice, tissues were aseptically removed from the cats and frozen at $-80^{\circ} \mathrm{C}$. Tissues were then thawed and pulverized with a manually operated tissue grinder to make a $5 \%$ to $20 \%(\mathrm{w} / \mathrm{v})$ suspension using BME with antibiotics as a diluent. The suspensions were clarified by centrifugation $(10,000 \times \mathrm{g})$ for $3 \mathrm{~min}$ and $0.2 \mathrm{ml}$ was then added to the cell monolayers for $1 \mathrm{~h}$ at $31^{\circ} \mathrm{C}$ for TS-FIPV and $39^{\circ} \mathrm{C}$ for WT-FIPV. After incubation the tissue suspensions were removed and the monolayers were washed once with $\mathrm{BME}$ followed by the addition of $1 \mathrm{ml} \mathrm{BME}$. The plates were incubated at the optimal temperature for each virus and were observed for viral CPE daily for 7 days following inoculation. A standard virus neutralization test [7] was done with Mab-P on the virus positive tissue homogenates to confirm the presence of coronavirus. Cat tissues were examined by direct IFA for viral antigen.

\section{Results}

\section{In vitro temperature sensitivity}

The effect of incubation temperature on the in vitro growth of TS-FIPV is shown in Table 1. TS-FIPV had optimal infectivity when propagated and titrated

Table 1. Temperature sensitivity of TS-FIPV grown for $48 \mathrm{~h}$ at $31^{\circ} \mathrm{C}$ or $39^{\circ} \mathrm{C}$ and then assayed for infectivity at both temperatures

\begin{tabular}{lll}
\hline $\begin{array}{l}\text { Growth } \\
\text { temperature }\end{array}$ & \multicolumn{2}{l}{ Infectivity $\left(\mathrm{TCID}_{50} / \mathrm{ml}\right)$} \\
\cline { 2 - 3 } & $31^{\circ} \mathrm{C}$ & $39^{\circ} \mathrm{C}$ \\
\hline $31^{\circ} \mathrm{C}$ & $2.1 \times 10^{6}$ & $4.7 \times 10^{1}$ \\
$39^{\circ} \mathrm{C}$ & $2.1 \times 10^{4}$ & $4.7 \times 10^{1}$ \\
\hline
\end{tabular}


at $31{ }^{\circ} \mathrm{C}$. The $\mathrm{CPE}$ produced at $31^{\circ} \mathrm{C}$ was characterized by formation of syncytia. When grown at $31^{\circ} \mathrm{C}$, TS-FIPV showed infectivity initially when titrated at $39^{\circ} \mathrm{C}$. However, after 4 days at $39^{\circ} \mathrm{C} \mathrm{CPE}$ was observed on less than ten percent of the monolayer and all plaques that formed were healed within 5 days. When grown at $39^{\circ} \mathrm{C}$, TS-FIPV had no detectable infectivity when assayed at $39^{\circ} \mathrm{C}$, but showed minimal infectivity when assayed at $31^{\circ} \mathrm{C}$.

\section{Growth curves}

The growth curves (Fig. 1) show that TS-FIPV grown at $31^{\circ} \mathrm{C}$ appeared in the culture supernatant at approximately $8 \mathrm{~h}$ and then increased rapidly, reaching a maximum yield of virus at about $48 \mathrm{~h}$. This contrasts considerably with TSFIPV grown at $39^{\circ} \mathrm{C}$ which reached a titer of four logs by $18 \mathrm{~h}$ and then remained essentially stationary. It appears that TS-FIPV infected initially at $39^{\circ} \mathrm{C}$ but a defect expressed at $39^{\circ} \mathrm{C}$ prevented the virus from propagating as it would at $31{ }^{\circ} \mathrm{C}$. WT-FIPV propagated at $39^{\circ} \mathrm{C}$ has optimum virus production by $42 \mathrm{~h}$ followed by a rapid decline in virus yield. In contrast, WT-FIPV did not grow at $31^{\circ} \mathrm{C}$.

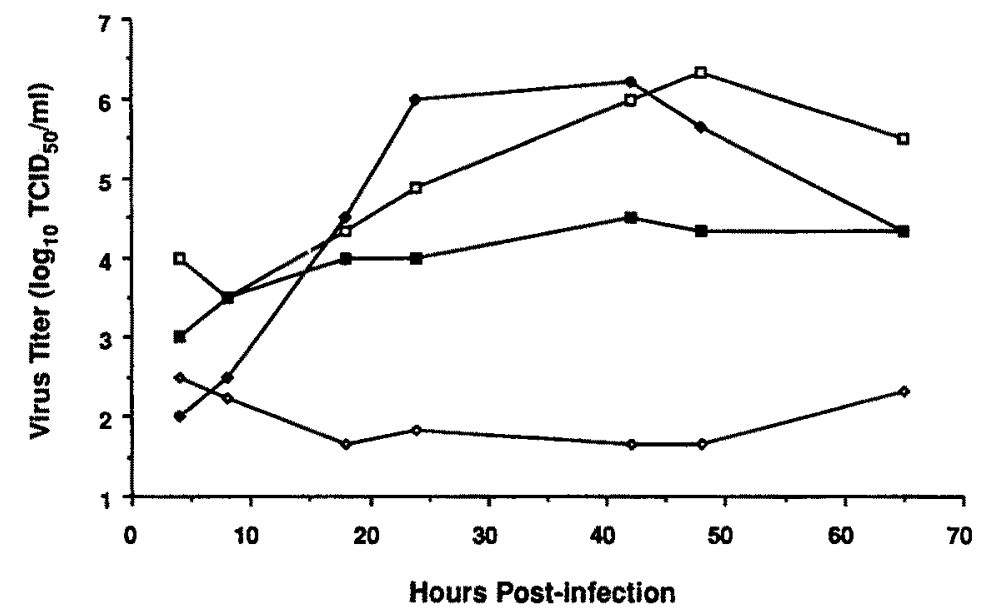

Fig. 1. Growth of FIP viruses on NLFK cells: TS-FIPV at $\square 31^{\circ} \mathrm{C}$ and $\square 39^{\circ} \mathrm{C}$ and WTFIPV at $\diamond 31^{\circ} \mathrm{C}$ and $\bullet 39^{\circ} \mathrm{C}$

\section{Plaque size}

Plaque assay results showed two distinct plaque types for WT-FIPV and TSFIPV at their optimal temperatures. WT-FIPV had large distinct plaques at $39^{\circ} \mathrm{C}, 1.0$ to $2.2 \mathrm{~mm}$, but none at $31^{\circ} \mathrm{C}$. Plaques for TS-FIPV at $31^{\circ} \mathrm{C}$ ranged in size from 0.5 to $1.0 \mathrm{~mm}$ and at $39^{\circ} \mathrm{C}$ no plaques were detected. 


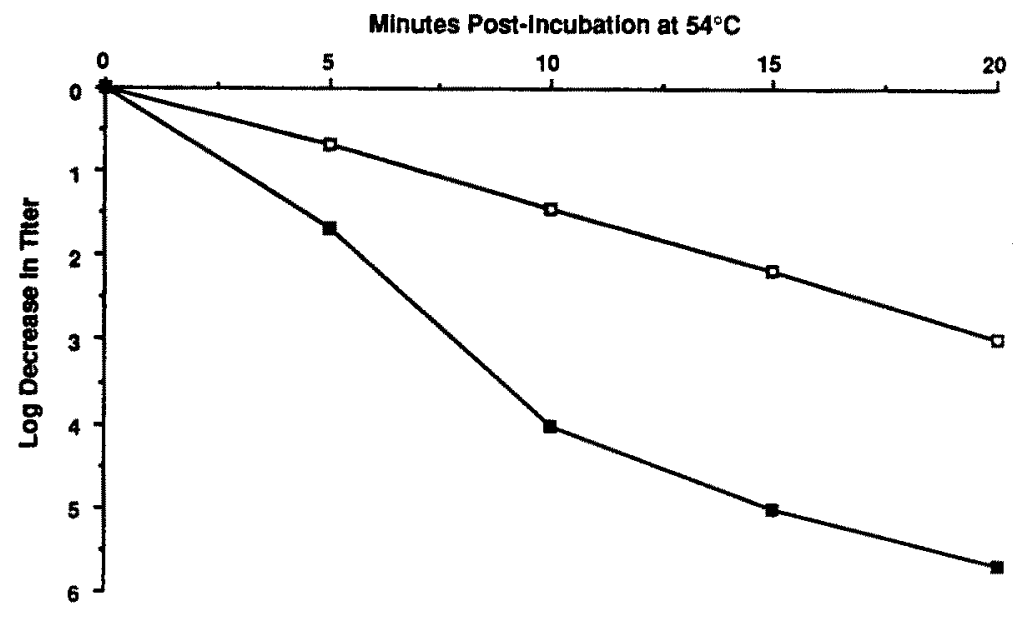

Fig. 2. Thermal inactivation of $\square$ WT-FIPV and $\square$ TS-FIPV at $54^{\circ} \mathrm{C}$

\section{Thermolability}

As can be seen in Fig. 2, TS-FIPV was rapidly inactivated at $54^{\circ} \mathrm{C}$. TS-FIPV infectivity decreased by five logs in $15 \mathrm{~min}$. WT-FIPV was more stable at $54^{\circ} \mathrm{C}$ than TS-FIPV since only two logs of infectious virus were inactivated within $15 \mathrm{~min}$.

\section{RNA synthesis}

The synthesis of TS-FIP virus-specific RNA, as measured by ${ }^{3} \mathrm{H}$-uridine incorporation, was compared at permissive and nonpermissive temperatures. Viral RNA synthesis at $31^{\circ} \mathrm{C}$ and $39^{\circ} \mathrm{C}$ was similar $12 \mathrm{~h}$ following infection, indicating that normal viral entry and initial synthesis occurred at the nonpermissive temperature. The ${ }^{3} \mathrm{H}$-uridine incorporation at $31^{\circ} \mathrm{C}$ was $98,920 \mathrm{cpm}$ and at $39^{\circ} \mathrm{C}$ was $95,913 \mathrm{cpm}$. However, a difference in the number of mature, infectious virions was apparent by $12 \mathrm{~h}$ post-infection. Virus grown for $12 \mathrm{~h}$ at the permissive temperature had a titer of $1.0 \times 10^{5} \mathrm{TCID}_{50} / \mathrm{ml}$, while virus grown at the nonpermissive temperature had a titer of only $2.1 \times 10^{3} \mathrm{TCID}_{50} / \mathrm{ml}$. Thus, at the nonpermissive temperature, it appears that early viral RNA synthesis occurred without a concomitant virus maturation process.

\section{Analysis of viral antigens}

The structural proteins of WT-FIPV and TS-FIPV grown at $39^{\circ} \mathrm{C}$ and $31^{\circ} \mathrm{C}$, respectively, were compared by Western blot using coronavirus-specific monoclonal antibodies. The Western blots showed that WT-FIPV and TS-FIPV had structural protein profiles characteristic of that reported for other coronaviruses [17]. The peplomer protein band had a molecular weight of $200 \mathrm{kDa}$ and the apparent molecular weight of nucleocapsid was $58 \mathrm{kDa}$ for both viruses (Fig. 3). Conspicuous differences appeared in the pattern of blotted envelope proteins for the wild type and temperature sensitive viruses. The WT-FIPV envelope 


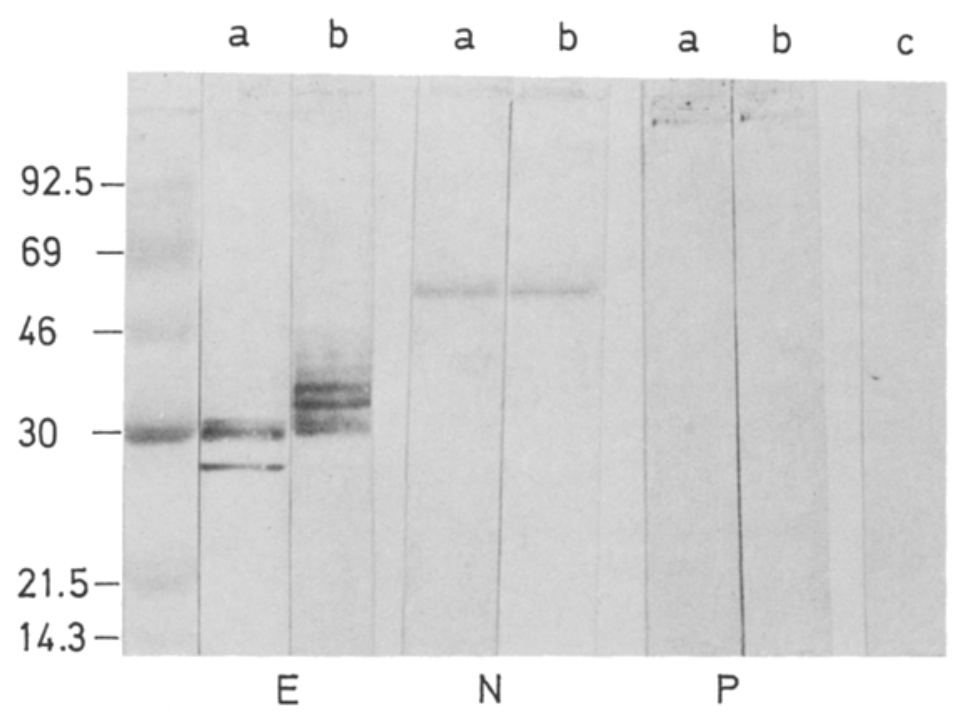

Fig. 3. Western blot comparison of $E$ envelope, $N$ nucleocapsid, and $P$ peplomer structural proteins of $a$ WT-FIPV and $b$ TS-FIPV. $c$ The monoclonal antibodies do not react with NLFK cell extract. Molecular weight markers $(\times 1,000)$ are at the left

protein consisted of $28 \mathrm{kDa}$ and $30 \mathrm{kDa}$ components (Fig. 3, E, a), whereas the envelope protein of TS-FIPV produced several protein bands from $30 \mathrm{kDa}$ to $46 \mathrm{kDa}$ (Fig. 3, E, b). The $28 \mathrm{kDa}$ component of TS-FIPV was present but not at the same intensity as it was for WT-FIPV. The differences in molecular weight of the envelope protein of the two viruses were confirmed using immune cat sera. Immune sera from both TS-FIPV vaccinated cats and WT-FIPV challenged cats showed the same differences in the envelope protein of the two viruses as did the monoclonal antibody (data not shown). Thus, the differences in the molecular weights of the envelope polypeptides were not due to differences in reactivity to the monoclonal antibody. There was not a difference in the molecular weights of the envelope polypeptides from TS-FIPV grown at $31^{\circ} \mathrm{C}$ or $39^{\circ} \mathrm{C}$ (data not shown). The specificity of the monoclonal antibodies used for antigen detection is demonstrated by the lack of reactivity with NLFK cell extracts (Fig. 3, c).

The culture supernatant from TS-FIPV infected cells was monitored for the appearance of structural proteins at both the permissive and nonpermissive temperatures. TS-FIPV grown at $31^{\circ} \mathrm{C}$ for $24,48,72$, or $96 \mathrm{~h}$ had all three structural proteins detected in the culture supernatant (Fig. 4A). When TSFIPV was grown at $39^{\circ} \mathrm{C}$ for similar lengths of time, only nucleocapsid was found (Fig. 4B). Nucleocapsid may be the only protein released at $39^{\circ} \mathrm{C}$ or the less abundant peplomer and envelope proteins were not detected. Figure 4 also shows that the nucleocapsid protein released at $39^{\circ} \mathrm{C}$ may be associated with infectious RNA or a few viral particles were released at $39^{\circ} \mathrm{C}$ because these culture supernatants were infective at $31^{\circ} \mathrm{C}$. However, at $24 \mathrm{~h}$ the infectivity of 


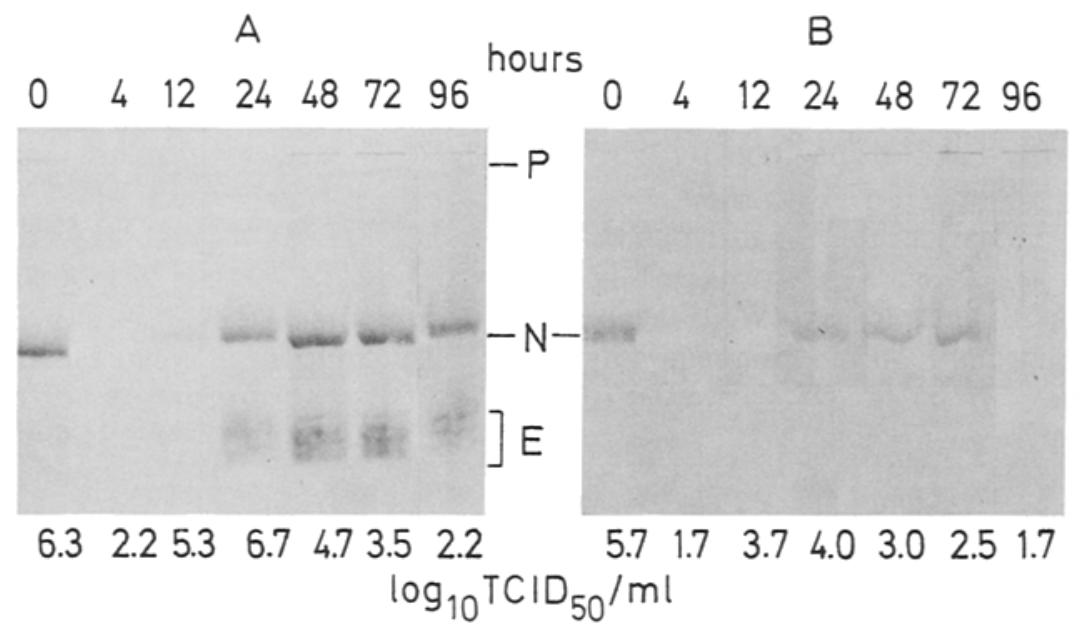

Fig. 4. Western blot detection of TS-FIPV structural proteins in culture supernatants of NLFK cells infected with TS-FIPV at a MOI of 10 for 4 to $96 \mathrm{~h}$ at $\mathbf{A} 31^{\circ} \mathrm{C} \mathrm{B} 39^{\circ} \mathrm{C}$. The virus titer $\left(\log _{10} \mathrm{TCID}_{50} / \mathrm{ml}\right)$ for each sample is shown at the bottom of each lane

the supernatant fluids from $39^{\circ} \mathrm{C}$ was almost three logs less than the supernatant fluids from $31^{\circ} \mathrm{C}$. When assayed at $39^{\circ} \mathrm{C}$, no detectable virus titer was found.

Intracellular synthesis of TS-FIPV and WT-FIPV proteins was compared at $31^{\circ} \mathrm{C}$ and $39^{\circ} \mathrm{C}$. Synthesis was monitored by IFA using coronavirus-specific monoclonal antibodies on acetone-fixed, infected cells. All three structural proteins of TS-FIPV were detected in the cells by IFA at both the permissive and nonpermissive temperatures (Table 2). The TS-FIPV proteins appeared at both temperatures within $6 \mathrm{~h}$ post-infection. Similar results were observed with WTFIPV infected cells at $39^{\circ} \mathrm{C}$. When incubated at $31^{\circ} \mathrm{C}$, WT-FIPV proteins appeared somewhat later. Nucleocapsid was visible by $8 \mathrm{~h}$ while peplomer and envelope proteins were apparent by $9 \mathrm{~h}$.

Examination of the surface of infected cells by immunofluorescence using a peplomer monoclonal antibody indicated that TS-FIPV was present on the surface of living cells by $12 \mathrm{~h}$ post-infection at $31^{\circ} \mathrm{C}$ but not $39^{\circ} \mathrm{C}$ (Table 2). Small areas of envelope surface fluorescence were observed for TS-FIPV by

Table 2. Indirect immunofluorescence detection of TS-FIPV and WT-FIPV proteins in acetone-fixed cells and on the surface of unfixed cells infected at $31^{\circ} \mathrm{C}$ and $39^{\circ} \mathrm{C}$

\begin{tabular}{llllll}
\hline & TS-FIPV & & \multicolumn{3}{l}{ WT-FIPV } \\
\cline { 2 - 3 } \cline { 5 - 6 } & Acetone-fixed & Surface & & Acetone-fixed & Surface \\
& $31^{\circ} \mathrm{C} / 39^{\circ} \mathrm{C}$ & $31^{\circ} \mathrm{C} / 39^{\circ} \mathrm{C}$ & & $31^{\circ} \mathrm{C} / 39^{\circ} \mathrm{C}$ & $31^{\circ} \mathrm{C} / 39^{\circ} \mathrm{C}$ \\
\hline Peplomer & $+/+$ & $+1-$ & $+1+$ & $+1+$ \\
Nucleocapsid & $+/+$ & $-1-$ & $+1+$ & $-1-$ \\
Envelope & $+/+$ & $+/-$ & $+1+$ & $-1+$ \\
\hline
\end{tabular}


$18 \mathrm{~h}$ at its permissive temperature only. After $12 \mathrm{~h}$ at $39^{\circ} \mathrm{C}$ peplomer and envelope antigens were detected on the surface of WT-FIPV infected cells, but at $31^{\circ} \mathrm{C}$ only slight peplomer fluorescence was found after $15 \mathrm{~h}$. Nucleocapsid was not detected on the surface of cells infected with either virus.

\section{In vivo fate of the virus}

In order to determine if the temperature sensitive characteristics of TS-FIPV observed in vitro were reflected by growth of the virus in vivo, cats were inoculated with either TS-FIPV or WT-FIPV. At predetermined times postinoculation, cats were sacrificed and tissues were examined for the presence of virus. Evidence of TS-FIPV replication in the upper respiratory tract was found by virus isolation and immunofluorescence (Table 3). Virus was isolated from the cervical lymph node, tonsil, trachea and turbinate at 1,2 , or 4 days postvaccination. TS-FIPV antigen was identified by direct IFA in the mandibular lymph node and the tonsil. In contrast, by 4 days after oral infection with WTFIPV, the virus had disseminated throughout the cat. WT-FIPV was isolated from four different lymph nodes (cervical, mandibular, mediastinal and mesenteric), the oral/nasal/pharyngeal area, as well as from the thymus and spleen. All of these tissues except the thymus were positive for viral antigen by direct IFA.

Table 3. Virus isolation and direct immunofluorescence assay on tissues of cats vaccinated intranasally with TS-FIPV or inoculated orally with WT-FIPV

\begin{tabular}{llllll}
\hline Tissue & \multicolumn{2}{c}{ TS-FIPV } & \multicolumn{2}{l}{ WT-FIPV } \\
\cline { 2 - 3 } \cline { 5 - 6 } & VI $^{\mathrm{a}}$ & IFA $^{\mathrm{b}}$ & VI & IFA \\
\hline Kidney & - & - & - & - \\
Liver & - & - & - & - \\
Lung & - & - & - & - \\
Cervical lymph node & + & - & + & + \\
Mandibular lymph node & - & + & + & + \\
Mediastinal lymph node & - & - & + & ND \\
Mesenteric lymph node & - & - & + & + \\
Pharynx & - & - & + & ND \\
Salivary gland & - & - & - & + \\
Spleen & - & - & + & + \\
Thymus & - & - & + & - \\
Tonsil & + & + & + & + \\
Trachea & + & - & + & + \\
Turbinate & + & - & + & + \\
\hline
\end{tabular}

a Virus isolation

${ }^{\mathrm{b}}$ Direct immunofluorescence assay

${ }^{c}$ Not done 


\section{Discussion}

The differences in the characteristics of TS-FIPV and WT-FIPV may account for the protective immunity afforded by TS-FIPV [5] and the onset of disease by WT-FIPV. TS-FIPV and WT-FIPV differ in temperature specificity and stability, plaque size, and structural protein expression. In addition, TS-FIPV and WT-FIPV disseminate differently in the cat. Although the lesions responsible for the temperature sensitive defect have not been located, the characteristics of TS-FIPV in relation to its parent strain suggest a maturation defect.

TS-FIPV growth is impaired at the optimal temperature $\left(39^{\circ} \mathrm{C}\right)$ for WTFIPV but TS-FIPV replicates normally at its permissive temperature $\left(31^{\circ} \mathrm{C}\right)$. This temperature preference allows TS-FIPV to grow in the upper respiratory tract of cats but retards systemic growth in cats where the temperature is $39^{\circ} \mathrm{C}$. Replication of TS-FIPV in the upper respiratory tract may stimulate mucosal responses that may be required to protect cats against FIPV challenge. Mucosal immunity provided by TS-FIPV may be important in stopping the primary infection of FIPV since Stoddart et al. [20] has shown that FIPV administered orally replicated initially in the tonsil and small intestine. Also, the temperature preference of TS-FIPV may prevent a vaccine-induced sensitization of the cat. This contrasts with a previous study by Pedersen and Black [14] in which vaccination with a modified-live FIPV not only failed to protect cats against disease, but appeared to sensitize cats so they were more susceptible to FIPV challenge than were nonvaccinated cats.

WT-FIPV produced larger plaques in NLFK cells than did TS-FIPV. Tupper et al. demonstrated that two virulent FIPV strains (79-1146 and NOR 15, a plaque purified DF2 WT-FIPV) produced larger plaques than the nonvirulent FECV strain 79-1683 [23]. McKeirnan and coworkers also documented this difference in plaquing profiles between these same feline coronavirus strains [11]. It appears that avirulent feline coronaviruses produce small plaques, whereas virulent FIPV produces large plaques.

TS-FIPV RNA synthesis occurred normally at $39^{\circ} \mathrm{C}$ for approximately $12 \mathrm{~h}$, even though viral growth did not proceed normally. The absence of intact virion production in the presence of RNA synthesis at $39^{\circ} \mathrm{C}$ suggests a defect in the maturation and assembly of the virion which has been shown in other temperature sensitive viruses $[3,4,21]$.

The detection of TS-FIPV structural proteins by indirect IFA in NLFK cells at $39^{\circ} \mathrm{C}$ without concomitant virus production also indicates a maturation defect at $39^{\circ} \mathrm{C}$. Surface expression of TS-FIPV and WT-FIPV peplomer and envelope proteins but not nucleocapsid at the optimal temperature for each virus resembles the situation in FIPV-infected macrophage-like cells [8]. The expression of viral antigen on the cell surface may be important in the pathogenesis of FIPV. The absence of TS-FIPV surface antigen at $39^{\circ} \mathrm{C}$ may account for the lack of sensitization in TS-FIPV vaccinated cats.

A difference was evident in the molecular weights of the envelope polypep- 
tides of TS-FIPV and WT-FIPV as shown by Western blotting. The low molecular weight ( $28 \mathrm{kDa}$ ) component was detected to a lesser degree for TS-FIPV than WT-FIPV. This same kind of difference was observed with two virulent strains of FIPV; UCD1 did not have the low molecular weight component that was present in the Dahlberg strain of FIPV [6]. These observed differences in the envelope protein may be due to differences in glycosylation. Further investigation by two-dimensional gels is needed to clearly differentiate the envelope proteins of TS-FIPV and WT-FIPV.

Different characteristics are apparent between TS-FIPV and its parent strain WT-FIPV. The importance of these TS-FIPV characteristics in relation to the protective response of the virus in cats is under investigation.

\section{Acknowledgements}

The authors thank Dr. B. Huseman for performing the necropsies and B. Suiter and Dr. M. Mellencamp for monoclonal antibody production. The critical review of this manuscript by Dr. W. Beckenhauer, S. Christianson, Dr. K. Haffer and Dr. A. Torres was greatly appreciated.

\section{References}

1. Barlough JE, Johnson-Lussenburg CM, Stoddart CA, Jacobson RH, Scott FW (1985) Experimental inoculation of cats with human coronavirus $229 \mathrm{E}$ and subsequent challenge with feline infectious peritonitis virus. Can J Comp Med 49: 303-307

2. Barlough JE, Stoddart CA, Jacobson GP, Scott FW (1984) Experimental inoculation of cats with canine coronavirus and subsequent challenge with feline infectious peritonitis virus. Lab Anim Sci 34: 592-597

3. Burge BW, Pfefferkorn ER (1966) Isolation and characterization of conditional-lethal mutants of sindbis virus. Virology 30: 204-213

4. Cooper PD, Johnson RT, Garwes DJ (1966) Physiological characterization of heatdefective (temperature-sensitive) poliovirus mutants: preliminary classification. Virology 30:638-649

5. Gerber JD, Ingersoll JD, Christianson KK, Selzer NL, Landon RL, Pfeiffer NE, Sharpee RL, Beckenhauer WH (1989) Protection against feline infectious peritonitis (FIP) by a temperature sensitive-FIP virus vaccine inoculated intranasally. Submitted for publication

6. Horzinek MC, Ederveen J, Egberink H, Jacobse-Geels HEL, Niewold T, Prins J (1986) Virion polypeptide specificity of immune complexes and antibodies in cats inoculated with feline infectious peritonitis virus. Am J Vet Res 47: 754-761

7. Ingersoll JD, Wylie DE (1988) Comparison of serologic assays for measurement of antibody response to coronavirus in cats. Am J Vet Res 49: 1472-1479

8. Jacobse-Geels HL, Horzinek MC (1983) Expression of feline infectious peritonitis coronavirus antigens on the surface of feline macrpohage-like cells. J Gen Virol 64: $1859-1866$

9. Laemmli UK (1970) Cleavage of structural proteins during the assembly of the head of bacteriophage T4. Nature 227: 680-685

10. Lutz H, Hauser B, Horzinek MC (1986) Feline infectious peritonitis (FIP)-the present state of knowledge. J Small Anim Prac 27: 108-116

11. McKeirnan AJ, Evermann JF, Davis EV, Ott RL (1987) Comparative properties of feline coronaviruses in vitro. Can J Vet Res $51: 212-216$ 
12. Miller TJ, Stephens DL, Mertz JE (1982) Kinetics of accumulation and processing of simian virus 40 RNA in Xenopus laevis oocytes injected with simian virus 40 DNA. Mol Cell Biol 2: 1581-1594

13. Oi VT, Herzenberg LA (1980) Immunoglobulin-producing hybrid cell lines. In: Mishell BB, Shiigi SM (ed) Selected methods in cellular immunology. Freeman, San Francisco, pp 351-372

14. Pedersen NC, Black JW (1983) Attempted immunization of cats against feline infectious peritonitis, using avirulent live virus or sublethal amounts of virulent virus. Am J Vet Res 44: 229-234

15. Pedersen NC, Floyd K (1985) Experimental studies with three new strains of feline infectious peritonitis virus: FIPV-UCD2, FIPV-UCD3, and FIPV-UCD4. Comp Cont Educ Prac Vet 7: 1001-1011

16. Reed LJ, Muench H (1938) A simple method for estimating fifty percent endpoints. Am J Hyg 27: 493-497

17. Siddell SG, Wege H, ter Meulen V (1983) The biology of coronaviruses. J Gen Virol 64: $761-776$

18. Stoddart CA, Scott FW (1989) Intrinsic resistance of feline peritoneal macrophages to coronavirus infection correlates with in vivo virulence. J Virol $63: 436-440$

19. Stoddart ME, Gaskell RM, Harbour DA, Gaskell CJ (1988) Virus shedding and immune responses in cats inoculated with cell culture-adapted feline infectious peritonitis virus. Vet Microbiol 16: 145-158

20. Stoddart ME, Gaskell RM, Harbour DA, Pearson GR (1988) The sites of early viral replication in feline infectious peritonitis. Vet Microbiol 18: 259-271

21. Tan KB, Sambrook JF, Bellett AJD (1969) Semliki forest temperature-sensitive mutants: isolation and characterization. Virology 38: 427-439

22. Towbin H, Staehelin T, Gordon J (1979) Electrophoretic transfer of proteins from polyacrylamide gels to nitrocellulose: procedure and some applications. Proc Natl Acad Sci USA $76: 4350-4354$

23. Tupper GT, Evermann JF, Russell RG, Thouless ME (1987) Antigenic and biological diversity of feline coronaviruses: feline infectious peritonitis and feline enteritis virus. Arch Virol 96: 29-38

24. Weiss RC, Scott FW (1981) Pathogenesis of feline infectious peritonitis: nature and development of viremia. Am J Vet Res 42: 382-390

25. Weiss RC, Scott FW (1981) Pathogenesis of feline infectious peritonitis: pathogenic changes and immunofluorescence. Am J Vet Res 42: 2036-2048

26. Woods RD, Pedersen NC (1979) Cross-protection studies between feline infectious peritonitis and porcine transmissible gastroenteritis viruses. Vet Microbiol 4: 11-16

Authors' address: K. Christianson, Biological Research and Development, Norden Laboratories, P.O. Box 80809, Lincoln, NB 68501, U.S.A.

Received July 24, 1989 